\title{
ISLAMIC EDUCATION AT MULTICULTURAL SCHOOLS
}

\author{
Irham \\ Universitas Islam 45 Bekasi \\ Jalan Cut Mutia No. 83, Margahayu, Bekasi, Jawa Barat, Indonesia 17113 \\ Email:irham@unisma.ac.id
}

Received: 08, 2017. Accepted: 12, 2017. Published: 12, 2017.

\begin{abstract}
This article aims to explain the roles of PAI (Pendidikan Agama Islam/Islamic Education) at multicultural schools. It was the results of the field research by using a qualitative method. The research was conducted at SMA (Sekolah Menengah Atas/Senior High School) Plus Pembangunan Jaya Bintaro Tangerang. The school was selected because its students had diversity of backgrounds, and the school had committed to develop the multicultural insights. Data of research were obtained through interview, observation, and documentation. The results showed that PAI had the roles as the pluralism moral activator to students. PAI was applied in the educational process to form students' multicultural attitude and thought. There were two underlying findings, namely: type of inclusive educators and design of multicultural curriculum.

Keywords: Inclusive, Islamic Education, Multicultural.

ABSTRAK

Artikel ini bertujuan untuke memaparkan peran serta PAI (Pendidikan Agama Islam) di sekolah multikultural. Artikel ini merupakan hasil penelitian lapangan dengan menggunakan metode kualitatif. Tempat yang menjadi objek penelitian adalah SMA Plus Pembangunan Jaya Bintaro Tangerang. Sekolah tersebut dipilib dengan alasan peserta didik memiliki latar belakang yang beragam dan sekolah memiliki komitmen dalam mengembangkan wawasan multikultural. Data penelitian diperoleh melalui wawancara, pengamatan terlibat dan dokumentasi. Hasil penelitian menunjukkan bahwa PAI memiliki peran sebagai penggerak moral kemajemukan kepada peserta didik. PAI diterapkan pada proses pembelajaran untuk. membentuk sikap maupun pemikiran peserta didik yang berwawasan multikultural. Ada dua temuan yang mendasarinya, yaitu tipe pendidik yang inklusiv dan desain kurikulum yang berwawasan multikultural.
\end{abstract}

Kata Kunci: Inklusif, Pendidikan Agama Islam, Multikultural.

\section{INTRODUCTION}

The presence of religion normatively brings a mercy. As a religion brought by Muhammad, Islam brings mercy to the universe (rahmatan lil alamin) (Al-Zamakhshari, 1997, p. 170). Nevertheless, when it comes to religious education practice, religion might not carry mercy. Religious education often contradicts the purpose of religion presence. It is used as ideology media of the certain sects or as legitimation to strengthen the certain views. Boutieri (2013) stated what makes the process of transferring the Islamic teachings to the human being fails is because the religious education cannot embody the humanistic education. He emphasizes that religious education should be explored using appropriate educational approach and process to achieve modern civilization.

Barnes (2006) added that religious education in many cases has taken wrong way to deliver religious character which have social objectives. The religious education should not only review theology but also become the media to discuss the socio-culture issues, including the issues concerning democracy. It has failed to build students' inclusive attitude because of its repeated material delivered to the students. This practice is not necessary. It is too formalistic and merely transfers the knowledge of religious norms (Rahim, 2001, p. 12). The condition is made worse 
by the low competence of religion teachers. Religion teachers teach with the normative approach, and oriented to cognitive side, not to affective side (Hasan, 2012).

Butt (2012) said that the colleges of religious education are the sources of radical ideology which essentially creates a social chaos. This is in line with the results of research conducted by PPIM (Pusat Pengkajian Islam dan Masyarakat/The Research Center for Islam and Society) at UIN (Universitas Islam Negeri) Syarif Hidayatullah Jakarta, that there were many teachers of PAI having exclusive views and intolerant attitude (Darmadi, 2016).

The issues highlighted above show the imbalance between the purposes of religious presence and the implementation of religious education, especially which is related to socioculture life. Therefore, the religious education in its implementation should be able to keep and bring the balance between history and reflectivity as well as tradition and enlightenment. Thereby, applying this notion, the religious education can be the solution from the above issues (Meijer, 2010).

This study seeks to explore and strengthen Meijer's view, particularly on PAI subject in transforming the religious values related to socio-cultural life, especially in pluralistic society life. In particular, this article tries to put forward the roles and the approaches of PAI at SMA Plus Pembangunan Jaya Bintaro Tangerang in activating the pluralism moral to students to create the modern civilization society.

\section{METHOD}

This study was qualitative in nature. It was conducted at a private-public school; that is, SMA Plus Pembangunan Jaya Bintaro Tangerang. The data of research were acquired through the interview, observation, and the documentation. The interview was conducted to the teachers of Islamic religion, the principal, the students, and the school security. The observation was conducted related to the learning activities at school, particularly on the subject of PAI. The school documentation was gained from the website, the recorded school data, a guidebook, the syllabus, and the lesson plan of PAI. The data obtained were then analyzed by triangulation and field crosscheck. Then the data were sorted and categorized to be analyzed using theory of multicultural education.

\section{RESULTS AND DISCUSSION}

\section{Profile of SMA Plus Pembangunan Jaya Bintaro Tangerang}

SMA Plus Pembangunan Jaya Bintaro Tangerang is the pioneer of international standard school which was built by Yayasan Pendidikan Jaya. It is located at the street of Taman Makam Bahagia ABRI Jombang Pondok Aren Bintaro Jaya Sektor IX Tangerang regency, Banten province. It run educational process by adhering three main values; First, professional, that is, working by always developing the expertise, innovation, creativity, and having integrity, honesty, commitment, and responsibility; second, exemplary, it is to give an example how to behave good, polite, fair, and wise; (dignified). It is the awareness as part of world civilization by appreciating and respecting the diversity, nationally-cultured, Pancasila-ism, patriotic, noble, and having a tolerant personality.

In developing the education, the school implements three integrated balance domains involving the attitude (attitude and excellent behavior), skill (the expertise for life preparation in the future), and knowledge (the integrated knowledge completeness). The school's vision is to become a national school with the best international standard which actively embodies Indonesian people who are fond of studying, creative, independent and noble. It also seeks to achieve its missions namely: 1) generating the students with high achievement and being able to compete to continue studies to the well-known colleges in national and international levels; 2) integrating the curriculum, the methodology and the continuous programs based on science, 
liberal arts, sustainable eco development and entrepreneurship which produce the humans who are fond of studying, creative, independent and noble; 3) developing the academic culture and the organization culture which will be the anvils of academic activity life and form the students' personality; and 4) becoming the pride Pembangunan Jaya group as a public school which appreciates the diversity/multiculturalism, tolerance and dignity.

Students' religious background at SMA Plus in the 2015-2016 academic years showed their pluralistic demography. Out of 429 students, 93\% belonged to Islam religion and statistically made it the majority. The Protestant Christianity was $2.8 \%$, the Catholic Christianity was 2.6 $\%$, and Hinduism was 1.6\%. In the 2015-2016 academic years, there was no Buddhism and Confucius.

Teachers and other supporting educational staffs were heterogeneous. Their number was 32 people and they were supported by the security and the cleaning service. In terms of religion, educators and education staff belonged to Islam were $78.2 \%$, the Protestant Christianity was $12.5 \%$, the Catholic Christianity was $6.2 \%$, and the Buddhism was $3.1 \%$.

In terms of educational degree, there were 8 people serving as the educators and the educational staffs with magister academic background. Others graduated from bachelor were 24 people. Based on their origin, they came from Central Java, East Java, West Java, Jakarta, Banten, West Sumatra, South Sumatra, and Sulawesi (Data of School, 2015-2016).

In implementation of academic activities, there are two forms of curriculum applied. The first one is the core curriculum consisting of the 2013 national curriculum (K-13 / Kurikulum 2013), and the second one is excellence curriculum. The excellence curriculum consists of science, entrepreneurship, liberal art, and sustainable eco-development. It is a typical feature that this school features to the public as its distinction.

\section{Multicultural Approach}

In social life, diversity and plurality create the diversity which are the natural things in life. In Arabic language it is called al-mukbtalif/al-mukhalafah/al-munawni'u (Munawwir, 1997, p. 362). In accordance with socio-cultural contexts, Banks (2008, p. 26) mentioned that diversity is divided into 8 categories, namely: gender diversity, sexual orientation, religion/faith, ability and disability, language, race group, ethnic identity, and social class.

The diversity does not bring advantages to society immediately. If it is not well managed, it will likely to bring conflicts. Social conflict happens everywhere. It has occurred in Indonesia. The cause of the conflict was various such as separatism, monetary crisis, and national diversity like tribe, ethnic, religion, race and culture. Some conflicts are triggered because of global influences (Hadi, 2007). They also have occurred in western countries. For example, the horizontal conflict between the black group and the white one. To overcome the conflict, the westerners developed the concept of multiculturalism. This concept tries to manage the diversity and the plurality so as the society where they belong remain harmonious. Kymlicka outlined the multiculturalism as a concept to build the social tolerance, the social justice, and to embody the democracy. This concept not only stops on the ideas, but also grows to be political policy. The existence of this effort in the political policy is to reinforce the system of liberal democracy (Kymlicka, 2010).

Multiculturalism, as the worldview, always emphasizes to some extent the willingness and acceptance towards the multicultural society's reality, its diversity for sure, and the acceptance towards the religious reality in the social life. It refers to the effort that people thrive to keep and maintain the diversity and plurality of society where they live (Azra, 2007). It is also considered as an ideology - the belief system which is determined by the existence of heterogeneous cultures. Applying this notion in pluralistic society, multiculturalism is called cultural politics (Nata, 2014, p. 235-254). 
To develop multiculturalism, systematic and measurable efforts can be done by the society through education. Cultivating multiculturalism in education allows society to explore the public space in enriching various talents or abilities, culture, history, and the experiences which represent the diversity. Previous studies clarify that the multicultural-based education helps students develop their positive identities, think critically, and become the democratic citizens. In addition, they will be able to see and manage wisely the world challenges that they face like racism phenomena, poverty, violence and humans' basic rights and build their inclusivity behavior (Ghosh and Galczynski, 2014, pp. 1-25).

Multicultural education is the effective strategy to be applied to the plural society. It serves as possible solution to a contradictory people and those who have a conflict caused by their misunderstanding and cultural difference. It tries to create a good, reliable, and harmonious friendship relationship among others in the society they exist (Wei, 2013). In this case, an expert of multicultural education, Banks, explains that the multicultural education is a theory believing in the truth to recognize the existence of human beings over their diversity. The multicultural education is designed to help the unity in the divided and different nation to unite one another (Banks, 2008, p. 8-11). In other words, it can be viewed as a strategy, that education exhibit to maintain and keep plurality of a particular society (Azra, 2007).

Multicultural education is the form of educational transformation. There are at least three transformations involved: first, the transformation of self. It requires the educators to develop the comprehension universally to the students. Second, the transformation of schools and schooling which describes the school's involvement in all aspects. Third, the transformation of society which shows the proactive occurrence in contribution towards social life, like embodying the social justice locally, nationally and globally (Gorski 2005, p. 13-15).

More particularly, Tilaar (2004, pp. 185-190) clarifies that there are six dimensions in developing the multicultural education in Indonesia. Firstly, it should uphold the rights of culture and identity of local culture. Secondly, it should direct to the value system as the national guidance. Thirdly, it should not only recognize the existence of cultural plurality from ethnic groups in Indonesia, but also actualizes the cultures itself. Fourthly, it should strive to play as social reconstruction that is an effort to see the existing social life today. Fifthly, it calls for the new pedagogy which constitutes the pedagogy of empowerment and the pedagogy of equality with human beings and various cultures. Sixthly, it aims to embody Indonesia's visions and ethics in nation. This concept is a little different from the ones which were developed by the western multicultural education. It tries to adopt the multicultural education in keeping with Indonesia's characters and cultures.

The concept of multicultural education seems compatible with Islamic views. Islamic teachings guide human being to know each other among their diversity as said in Qur'an. alHujurät: 13. Al-Zamakhshari, in his interpretation, elaborates that there are two important things in this verse. Firstly, the form of human existence is the certainty, that the humans are heterogeneous and plural that can be seen from gender difference and have the nations and the ethnic groups. Secondly, knowing each other (lita'ärafu). Further, he explains that the term lita'ärafu means to understand, comprehend, and adapt one another among those who are heterogeneous and different. It means not to brag or boast each other among them because of caste and family or the higher social status (egocentrism). Afterwards, this verse emphasizes again that the noblest person besides God is not because of the caste, family, ethnic group, or lots of wealth but piety to his God (Al-Zamakhshari, 1997, p. 585).

The term (lita'ärafu) which promotes diversity demonstrates Islamic view of multiculturalism. It can be seen as the effort to know each other, create tolerance, respect humanity, democracy, justice. It also prohibits the behavior that leads to conflict because of the diversity existed in the society where they live.s. Qur'an. al-Hujurät: 13 also has something to do 
with Qur'an. al-Rum: 22 regarding the principles of plurality stating that the difference should be positively accepted because that is the token of Allah's omnipotence. Diversity should be managed wisely and it should be a starting point to compete leading to goodness (Lajnah Pentashihan Mushaf Al-Quran, 2014, p. 23-24).

\section{PAI and Its Implementation at SMA Plus Pembangunan Jaya Bintaro Tangerang as A Multicultural Schools}

SMA Plus Pembangunan Jaya Bintaro Tangerang has a commitment to enforce the educational programs with international and cultural standard, make the noble students who are able to live in multicultural society. Its school commitment is clearly described in its vision and missions which are known to the public. It promotes multicultural education which is very clearly mentioned in the fourth mission; that is, the public school which appreciates the diversity. It applies multicultural education to each program of school, including in subject of PAI.

The term PAI has two different understandings. Firstly, PAI, viewed as educational practice, is enforced by Islamic Institutes, such as: madrasah, pesantren, and Islamic schools. Secondly, PAI, viewed as a subject, refers to subject taught in the class like other subjects such as: history, mathematics, biology, and other subjects at schools. These two definitions are parallel to what Kodelja (2012) says, there are two religious educations: those are, the religious education which is enforced at certain religious schools and the religious education in the form of subject of religions at public schools. In this research, the definition applied refers to the second understanding; that is, PAI as the subject which is enforced at SMA Plus Pembangunan Jaya Bintaro Tangerang as a public school.

SMA Plus Pembangunan Jaya Bintaro Tangerang applies the 2013 national curriculum (K13) and curriculum of liberal art as the excellence curriculum. As one of the subject in the curriculum, PAI has an important role in developing multicultural education. This happens because there are two supporting factors available in the school. Firstly, it is related to inclusivity PAI teachers, and Secondly it is related to the curriculum.

\section{Educators' Inclusivity}

The success of multicultural education is determined by educators' inclusivity. An educator can be the first starting point when seeing the application of multicultural education at schools. If they have not met the inclusive criteria, then it cannot yet be said that the multicultural education has been working. Banks clarifies that the open-minded school staffs have the positive hopes towards the diversity of students. These staffs are an important element in enforcing the multicultural schools (Banks, 2008, p. 111-120).

The school has two PAI teachers, their names are Iwan Ridwan and Ahmad Dahlan. Ridwan began teaching in 2001. He graduated from Arabic Education, UIN Sunan Gunung Djati Bandung. In addition to PAI teacher, he serves as head in public relation department. His teaching hours were less than Dahlan's because of additional task in school management. He explained that the school had tried to develop the multicultural education so that the school has tried to recruit the educator staffs having good competence and commitment for multicultural education..

Other teacher is Ahmad Dahlan. He began teaching in 2010. He graduated in 2010 from UIN Syarif Hidayatullah Jakarta majoring in Islamic Education Program. His worldview on multicultural education was gained from the experience he took from UIN Syarif Hidayatullah Jakarta. As one of the leading Islamic university under minister of religion affair, UIN Jakarta has paradigm to integrate the science and religion which have been so long regarded, in national and international, as dichotomous between religious science and secular science (Abdillah, 
2015). It features education that certainly many times formed Dahlan's character, thoughts, and behavior.

PAI teacher especially at SMA Plus Pembangunan Jaya Bintaro Tangerang can be explored through motives of becoming the teachers of religion at the school. At first, Dahlan wanted to be the teacher at the school because of his interests towards the model of learning at multicultural schools and diversity of students' backgrounds. He thought that nothing the matter with the diversity and the plurality in life. The diversity and the plurality become an interesting thing to be understood, especially in educational world. When it comes to interview, he had been asked by the school management related to his religious understandings and how to deal with the diversity. He could point out the inclusive attitude and appreciate the diversity, so that the school management accepted him as a teacher of PAI at the school. According to Dahlan (personal communication, July 6, 2015) in fact every teaching of religion was good, so that it was not necessary to say right and wrong towards the teachings of other religions. Thus, there is nothing the matter with the diversity of students' religion backgrounds. In this case, every applicant which is accepted as a staff or an educator is the one who has the inclusive attitude and thoughts (Ridwan, personal communication, October 9, 2015).

Dahlan in the process of teaching looked very creative and open. He applied principles of critical thinking and open to the students. For instance, in the contexts of teachings of religious tolerance according to PAI, he tried to give the understandings of Islamic teachings related to the teachings of tolerance. He posed students a question. He asked why students need to be tolerant towards other religions. This question stimulated the students in order to think critically. Then the students were asked to give the pluralist figures pointing out the tolerance among the religious mankind. This could give students a lesson by finding out about pluralist figures and how are their attitudes and thoughts. On the other hand, he along with the other teachers of religion plans to carry out an inter-religious seminar on the excellent curriculum.

The above findings show that Dahlan has the criteria of inclusive educator. The inclusive criteria can demonstrate that the character of PAI at SMA Plus Pembangunan Jaya Bintaro Tangerang as the multicultural education has qualified. According to Banks, the educators' and educational staffs' inclusive character determines the social structure and the school culture. Thus, students' diverse backgrounds was no longer a problem, and everyone can receive equal education service. It all is important in developing the multicultural education (Banks, 2008).

Being a multicultural school, it has recruited the open-minded teaching staffs. The school has a mission to uphold multicultural education. This mission is not different from the development of the multicultural education committed by AGPAII (Asosiasi Guru Pendidikan Agama Islam Indonesia/Association for Teachers of Islamic Education in Indonesia ). AGPAII was established on 27th March 2007 as an organization in which the teachers of PAI all over Indonesia take shelter. It has many branches in province and regency/city. Starting the program for development of multicultural education, it utilizes an approach through empowerment of teachers of PAI with various instruments. The empowerment of teachers becomes the main thing because the curriculum which is designed in standard of multicultural education will not be effective if it is not accompanied by educators' ability (Al-Makassary \& Suparto, 2010).

\section{The Double Curriculum}

SMA Plus Pembangunan Jaya Bintaro Tangerang uses two formal curriculums. The first one is the 2013 national curriculum (K-13) and the second one is the excellence curriculum. The two curriculums are implemented in the school. They are carried out in accordance with the appointed schedule between the national curriculum and the excellent curriculum which the school strive to achieve in educating its students.

The excellence curriculum having the roles in developing the multiculturalism at schools is called curriculum of liberal art. The excellent curriculum consists of religious education, civic 
education, English language, Plus English language, Chinese language and sociology. Each formal curriculum which applies at SMA Plus Pembangunan Jaya Bintaro Tangerang will be elaborated as follows:

\section{The 2013 Curriculum (K-13)}

SMA Plus Pembangunan Jaya Bintaro Tangerang applies the K-13 since this curriculum was officially formalized by the government. PAI in the K-13 not only deepens on the religious teachings, but also has a role to implant sensibleness, so that the subject is called PAI and sensibleness. The two entities are united, the integrated religious values with sensibleness, although the sensibleness in the K-13 does not mention its competence.

The K-13 has KI (Kompetensi Inti/core competence) and KD (Kompetensi Dasar/Basic Competence). The KI which is meant in the K-13 is four, namely: spiritual competence (KI-1), social competence (KI-2), knowledge competence (KI-3) and skill competence (KI-4). Basic competence in the K-13 requires that all subjects must be oriented to the formation of core competence. So, the whole subjects existing at school contribute to the formation of spirituality, attitude, knowledge and skills, including the subject of PAI.

The K-13 integrates KD and $\mathrm{KI}$ on all subjects. The existence of this integration requires all subjects which are not original to develop science and skills; however, it can be related to the spiritual and social values. The social competence shows that the K-13 tries to develop the multicultural education. The objective of the multicultural education is to develop the social competence.

The K-13 is in accordance with the principles of multicultural education. Students' talents can be associated in accordance with interests. According to Banks, the multicultural education tries to develop students' potencies based on their abilities, so that each of students' talents can burgeon (Banks, 2008, p. 1-6).

Learning implementation of PAI at SMA Plus Pembangunan Jaya Bintaro Tangerang uses the scientific method. The stages of scientific method are according to the clue of syllabus of $\mathrm{K}-13$; those are, observing, questioning, exploring, associating, communicating, and reflecting. The approaches used are transformative and thematic. The transformative approach is applied when presenting the materials which have been prepared and integrated with other materials according to $\mathrm{KI}$ and $\mathrm{KD}$. In transformative approach, teacher explains PAI material with assistance from other perspective, such as by delivering quranic verses. For example in explaining about honesty, the teacher explain QS. al-Māidah and clarifies the importance of honesty in society. Values which exist in society are amanah and honesty in doing the duties of organization in society. Thus, the religious teachings and the social reality about honesty can be related. This approach is according to the K-13 in integrating the KD and the KI.

The thematic approach is committed by forming the students' group to review the themes which have been prepared. The PAI teachers have prepared the themes which will be conveyed to the studen's taken from syllabus. An example of theme PAI learning is the Islamic leadership and Prophet's examples. Each group discusses the theme. The results of discussion are in turn presented in front of the class. After they have presented, other groups stand a chance of responding to them. This approach can explore students' comprehension and build the independence in finding a solution related to the discussed theme. In the practice of learning as explained above, Gorski called it the school transformation and the social transformation in the multicultural education (Gorski, 2005, p. 13-15).

According to Dahlan the implementation of K-13 on the subject of PAI can work in accordance with the concepts of K-13. The hindrance which he deals with on the application of $\mathrm{K}-13$ of PAI is on the process of assessment encompassing 4 KIs. The assessment is inhibited by the limited time; consequently, it is not fully done by him. 
Since the government launches new curriculum, the K-13 has been applied at schools. Suhadi et.al, (2014, p. 33-39) put forward the critical aspects of PAI on the K-13; those are, 1) the dogma contents are too big as a result of tending to stick out the emphasis of Islamic identity; 2) reflection and enthusiasm of appreciating the diversity are minimum. PAI on the K-13 is still less in giving the development of inclusive attitude and the openness because most of students' study burdens are to memorize the Quran and to understand the practice of worship. So, the students are pressed more on the mastery of cognitive aspects than on the very important reflective aspects; and 3) the religious interaction is limited. Almost all materials of PAI are oriented to deepen the Islamic materials and restrict the self very much towards orientation of understanding the diversity of religions.

The K-13, especially on the subject of PAI, can be called curriculum of uniform - the concept of curriculum centered from the government for schools from up to down. According to Tilaar, such curriculum contains an indoctrination which neglects the existing potencies at each school. The local wisdom existing at schools does not function due to the existence of centralization. The curriculum ought to be designed by the school itself which is adjusted with students' needs. Curriculum with this model is more universal and unlimited on the certain teachings (Tilaar, 2012, p. 356-358).

In the implementation, not all teachers are able to implement the K-13. The hot issues related to the implementation of $\mathrm{K}-13$ are because the school is not ready to implement the curriculum, and the school facilities are inadequate. Its unpreparedness is because the teachers at the school have not had the adequate competence in integrating the $\mathrm{KD}$ and the KI. To integrate the KD and the KI, they should be creative and innovative. they are demanded to have wide insights. Therefore, learning process, they should not depend on materials or guides in the books.

\section{Curriculum of Liberal Art}

Curriculum of liberal art is part of excellent curriculum at SMA Plus Pembangunan Jaya Bintaro Tangerang. It aims to develop the multicultural insights. Its basic principle of PAI is to convey the religious tolerance. Its implementation is eligible to the grades X and XI. It is no longer applied in the grade XII because the grade XII is focused on preparing the national examination. In this review, what is hogging is the implementation of PAI in the 2014-2105 academic years. Clarifications about the implementation, material, method of learning, and evaluation of PAI will be presented below.

1. Time of implementation.

Curriculum of liberal art is applied at SMA Plus Pembangunan Jaya Bintaro Tangerang four months after the implementation of K-13 in every new academic year. Four months after the application of curriculum of liberal art, the learning at SMA Plus Pembangunan Jaya Bintaro Tangerang is continued again by applying the K-13. In the implementation of K-13, students are grouped based on their religions; however, in the implementation of curriculum of liberal art, the students are not separated based on their religions. All teachers of religion are present in accordance with students' religions in the class. For example, if there are three different religions in a class, then there are three teachers of religion in the class.

2. Materials of PAI.

The materials of PAI in the curriculum of liberal art are adjusted with the principles of religious multiculturalism. Mechanism of planning the materials of PAI is committed through a discussion together with teachers of religion at school. The discussion discusses the big theme which will be adopted together and plans the learning scenario. PAI of curriculum of liberal art tries to develop the universal big themes related to tolerance, democracy, and humanism, whose substance directs to multiculturalism (Dahlan, personal communication, July 6, 2015). Those 
themes are in line with Nata's view stating that tolerance, democracy, humanism, and humans' basic rights are parts of the multiculturalism components (Nata, 2014, p. 235-254).

In the 2014-2015 academic years, the big theme adopted is religious togetherness. The big theme is divided into subthemes which are then made the learning materials. The division of materials from the theme is also related to the materials existing on the K-13.

This curriculum development of PAI of liberal art is part of transformation in educational curriculum. This form of transformation is an integration liberal curriculum art from the more general and multicultural themes which have been planned by teachers of religion with religious perspectives. This transformation can enlarge students' comprehension over the certain themes. This is in line with stating that the transformation in education is transforming the skills to enlarge the global views and awareness through critical reflection to know other cultures and languages from various different backgrounds (Kramsch, 2013).

According to Banks, transformation of curriculum is as an approach in integrating the socio-culture contents into a curriculum. The main objective of this approach is to help students to understand the concepts, events, and humans from different cultural/ethnic perspectives and to understand the construction of social science. The transformative curriculum helps develop the multicultural education which can make students know, care, and act in embodying experiences and empowerments of democratic culture. So, it is not enough only to know and to understand the knowledge related to multiculturalism, and this is not helpful enough for students to develop empathy, caring about the commitment of humanism and changes to the more democratic direction. The most essential objective in developing the multicultural curriculum is helping students to develop their empathy and care (Banks, 2008, p. 47-50).

This transformation curriculum form of PAI is also according to the functions of multicultural education as mentioned by Gorski (2005, p. 13-15) regarding to selftransformation, school transformation, and social transformation. With this approach model, PAI gives the religious competence not only on students' internal side but also on their external side. Integration PAI materials with the main themes related to multiculturalism is carried out by a trans-discipline approach to provide students so that they can overcome various problems which they encounter (Mawardi, 2013).

3. Methods of learning.

The methods used in the learning implementation of PAI are various. For example, when reviewing material of enmity, the material is conceptually reviewed based on respective religious perspectives. Then the learning is followed by dialogue or discussion together. In this chance, students are encouraged to give responses or comments by relating the material of enmity to the case occurring in society. So, by way of the discussion, there can be the synchronization between religious concepts and social facts.

The other learning methods used PAI learning are the independent inquiry method. Students carry out the inquiry method by searching for the findings through literature or find the social facts by visiting the society. For example, the teacher asks the students to express the events of religious tolerance which they have ever encountered in society. To answer it, the students are grouped, and they read the literature or observe the surroundings. Then the students explain results of their findings, and the other students give the responses and the criticisms.

With inquiry method, students can find out by themselves the events related to the religious tolerance as well as the problems which have ever occurred in society. The inquiry method also helps teachers to understand students' views related the events happening in society. If there is a student's deviate view, for example a fundamental view, then the teacher of religion can justify it. The other teachers of religion also give their views according to their respective religious teachings. 
The inquiry method helps students become independent. This is recognized by Rami, a student in the grade X-IPA 1 (Ilmu Pengetabun Alam/Natural Science) stating that the learning model with the group discussion and the certain themes becomes a challenge for the students. The challenge makes students active to look for the materials according to themes (Rami, personal communication, January 19, 2016).

The learning model with theme selection is called thematic learning. The thematic model organizes the learning activities from one theme which can be reviewed by a few different ways and viewpoints, including by contextualizing the social facts. With this model, the theme reviewed can find the explanations deeply. In addition to enriching the scientific materials, such review of theme can develop the attitude which can give the esteem, the empathy, and the equity. These three things are expected to generate the multicultural education (Tiedt and Tiedt, 2005, p. 39).

The shared learning method used is, all students and teachers from different religions gather in a class and follow the learning, giving examples to the students that, all existing religions contain the same goodness and do not need there to be a difference. So, it can omit the skeptical attitude and thoughts towards other religions, building the attitude of openness in thinking and behaving, implanting the thoughtfulness, and tolerance over diversity.

4. System of evaluation.

System of evaluation on the curriculum of liberal art is not different from the standard of evaluation on the K-13. However, evaluation of curriculum of liberal art does not do the written test assessment, since the aim of the curriculum of liberal art is to build students' attitude. The evaluation system used is by observing the students when the learning activities take place. Observation is committed to assess the attitude and the view, as well as students' activities in the process of learning. The teacher gives students a final task to make the works. The final assignment is committed on the summit of curriculum of liberal art. In the 2014-2015 academic years, the final task given to students is making the works with the theme 'tolerance among religious mankind'.

\section{Curriculum of Liberal Art Summit}

Curriculum of liberal art has a summit curriculum. The meaning of summit curriculum is, at the end of enforcement of excellent curriculum, each component enforces the summit of the learning activities. The summit curriculum of liberal art functions to give the shared learning and to find out the development of students' attitude and thoughts. In the 2014-2015 academic years, the summit curriculum of PAI is divided into two parts: those are, the inter-religious seminar and making the works describing the tolerance among religious mankind. On the summit curriculum, PAI integrates along with other religious educations. The summit curriculum gives and implants the values universally to each religious education, such as: tolerance, togetherness, and harmony.

The inter-religious seminar committed on the summit curriculum is a scientific discussion by presenting the figures of religion besides the teachers of religion existing at school. The material which is delivered has something to do with the tolerance of religious mankind. Then the students stand a chance of questioning. In the seminar enforcement, all students associate in one room without any diversity.

Plan of activities on the summit curriculum is committed by all teachers of religion related to activities, materials, and determining the interviewees who will be invited. The reason why the activity of inter-religious seminar is chosen is, because it is according to the big theme which has been previously planned. The theme of seminar is the same as the big theme of the curriculum of liberal art in the field of religious education; that is, togetherness in religion.

The summit curriculum focuses on the theme of religious mankind tolerance which is actually the core of the big theme for togetherness in religion. The activities on the summit 
curriculum get the positive responses from students. The positive responses can be seen from many students who ask the questions on the seminar activities. Students in the grade IX are satisfied that they can discuss the unresolved problems (Rina, personal communication, July 6, 2015). On the summit activities, students can enlarge the insights of harmony and the tolerance among different religious mankind, can solve their problems, confirm and deepen the knowledge about religious tolerance. Students are increasingly aware of harmony and tolerance of religious mankind. This is what Jackson calls the inclusive school giving the media to hold a dialogue among students with different religions (Jackson, 2004, p. 167-168).

The inter-religious seminar becomes a place to discuss the diversity. The functions of multicultural education try to deepen and enlarge the interpersonal and international communications on economic problems, cultures, and other social problems, including religion. The diversity no longer becomes the problem; it can even be a chance to enrich experiences. In China, process of multiculturalism integration through English teaching becomes effective as media of transmission of different cultures, both from the West and from the East, because the integration of multiculturalism through a teaching gives the comprehension to know each other among students with cultures of minority towards the cultures of majority (Wei, 2013).

Another summit curriculum is making the works describing tolerance among religious mankind. The works point out students' comprehension and attitude towards tolerance of religious mankind. One of the works which is produced by students is a video entitled "Who is your God?" This video was created by a group of students whose religion is different number in seven people. Of the seven group members, two students are Christian, one student is Muslim, two others are Hindu, and the others are Buddhist. They act as the actors in the video. The video entitled "Who is your God?" describes the comprehension of each student about God. In that video, they tell that God is one, and it is because the humans' different understandings which make God different and various. They want to say that one God with people's perspectives is different. So, as religious mankind, we do not have to complicate the difference. This is an achievement in developing the multicultural attitude and including the aim to know each other (li ta'ärafu).

The forms of thinking and understanding about God can also be understood in theological religious typology on category of universalism believing that the truth is one. This type exceeds the inclusivism religious typology, since the type of inclusivism still has a view that, it has the truth out of its religion even though it is not fully the same as its religion. Type of universalism is a central point between pluralism and universalism in which the universalism recognizes the truth of God, the truth of soul, the universal intellectual and ethics which are available from God for the human race. It is the God who usually becomes the main approach over transcendence of religion (Bril, 2010, p. 16-17).

In Indonesian contexts, the multicultural society is relevant to reemphasize the national identity. The inclusive and tolerant Indonesia remains ingrained to its plural identity as reflected in basic concepts of the Pancasila State. Multicultural society becomes an institution to develop democracy and civil society in Indonesia (Ubaedillah, 2015, p. 74). In this case, PAI can support to form the students in order to have the multicultural insights. This finding shows that PAI is one of the approaches in developing students' plurality moral at schools. The findings in this research are different from what Boutieri puts forward. He states that religious education is not able to embody the humane and accommodative students as it is still ideological (Boutieri, 2013).

\section{CONCLUSION}

This article concludes that PAI has a role as the plurality moral activator to students. This plurality moral activator tries to encourage and create the multicultural attitude and thoughts to students through process of learning. This conclusion is based on the findings of research 
related to the implementation of PAI at SMA Plus Pembangunan Jaya Bintaro Tangerang having a commitment to develop the multicultural insights. The implementation of PAI in developing the multicultural insights applies two things: firstly, developing type of inclusive educators. Such educators are as the exemplary actors for students to develop the multicultural attitude and as the actors who implement the school programs having the multicultural dimensions. The second one is designing the multicultural curriculum. Curriculum which is doubly applied is the curriculum of PAI K-13 containing the integration between the KD and the KI, although in this curriculum there are still weaknesses and curriculum of liberal art. Curriculum of liberal art is as the curriculum of typically school or part of the excellent curriculum, whose objective is to develop the multicultural insights. The two curriculums are complementary. With this approach, PAI can deliver the religious missions as the mercy bringer for the universe. In summary, the findings of this study are not in line with the previous studies that revealed the religious education served as medium of cultivating ideology and supporting factors for cultivating exclusive behavior and thought.

\section{BIBLIOGRAPHY}

Abdillah, M. (2015). Integration of knowledge and its aplication in Islamic studies. In paper prasented in international seminar on Islamic studies and integration of knowledge: their implementation in teaching and research. by the graduate school, Syarif Hidayatullah State Islamic University (UIN) Jakarta.

Al-Makassary, R., \& Suparto (Eds.). (2010). Cerita sukses pendidikan multikultural di Indonesia. Jakarta: CSRC UIN Jakarta.

Al-Zamakhshari, A. al-Q. M. bin 'Umar. (1997). al-Kashshaf 'an haqaiq ghawamid al-tanzil wa 'uyun al-aqawil fi wujuh al-ta'wil. Al-Riyad: Maktabah al-'Abikan.

Azra, A. (2007). Keragaman Indonesia: Pancasila dan multikulturalisme dalam keragaman suku agama, ras, gender, sebagai modal sosial untuk demokrasi dan masyar kat madani: Tantangan dan peluang. Yogyakarta: Fakultas Psikologi UGM.

Barnes, P. (2006). The misrepresentation of religion in modern British (religious) education. British journal of educational studies, 54(4), 395-411. https://doi.org/10.1111/j.14678527.2006.00356.x

Banks, J. A. (2008). An introduction multicultural education. Boston: Pearson.

Boutieri, C. (2013). Inheritance, heritage, and the disinherited: ambiguities of religious pedagogy in the Moroccan Public School. Antropology \& Education Quartely, 44(4), 363-380. Retrieved from https: / /www.scopus.com/record/display.uri?eid=2-s2.0-84888238866\&origin= resultslist\&sort $=$ plff\&src $=s \& s t 1=$ Ambiguities + of + religious + pedagogy + in + the + Moroc $\mathrm{can}+$ Public + School\&st $2=\& \mathrm{sid}=8772241 \mathrm{feb} 7 \mathrm{de} 0$ efe $66 \mathrm{c} 6 \mathrm{fa} 65489 \mathrm{e} 02 \mathrm{~b} \& \mathrm{sot}=\mathrm{b} \& \mathrm{sdt}=\mathrm{b} \& \mathrm{~s}$ $1=78 \& \mathrm{~s}=$ TITLE-ABS-

$\mathrm{KEY} \% 28$ Ambiguities + of + religious + pedagogy + in + the + Moroccan + Public + School $\% 29$ \&relpos $=0 \&$ citeCnt $=3 \&$ search Term $=$

Bril, A. (2010). Judaism and other religions models of understanding. Palgrave Mcmillan.

Butt, T. M. (2012). Social and political role of madrassa: Perspectives of religious leaders in Pakistan. A Research Journal of South Asian Studie, 27(2), 387-407. Retrieved from http://pu.edu.pk/images/journal/csas/PDF/6.\%20Tahir\%20Mehmood\%20Butt_V28_ no2_12.pdf

Dahlan, Ahmad (2015, July 9). Personal communication.

Darmadi, D. (2016). Guru agama makin tak toleran. Retrieved September 20, 2017, from http://www.uinjkt.ac.id/id/guru-agama-makin-tak-toleran/ 
Ghosh, R., \& Galczynski, M. (2014). Redefining multicultural education inclusion and the right to be different. (3, Ed.). Toronto: Canadian Sholar's Press Inc.

Gorski, P. C. (2005). Multiculture education and the internet intersection and integrations, second edition. New York: McGraw-Hill.

Hadi, S. (2007). Disintegrasi pasca orde baru: Negara konflik lokal dan dinamika internasional. Jakarta: Yayasan Obor.

Hasan, K. T. (2012). Capaian dan pengaruh pendidikan agama dipertanyakan. Retrieved from https://kemenag.go.id/berita/read/104603

Jackson, R. (2004). Rethinking religious education and plurality issues in diversity and pedagogy. London: Routletge.

Kramsch, C. (2014). Teaching foreign languages in an era globalization: Introduction. The Modern Language Journal, 98(1), 296-311. http://dx.doi.org/10.1111/j.1540-4781.2014.12057.x

Kodelja, Z. (2012). Religious education and the teaching about religions. Śolsko Polje, Letnik, 23, 253-296. Retrieved from http://www.pei.si/UserFilesUpload/file/digitalna_knjiznica /SP/2012/\%C5\%A0olsko\%20polje,\%20XXII,\%20vol\%201-2,\%202012.pdf

Kymlicka, W. (2010). Testing the liberal multiculturalist hypothesis: Normative theories and social science evidence. Canadian Journal of Political Science, 42(2), 257-271. Retrieved from https://www.researchgate.net/publication/231747395_Testing_the_Liberal_Multicultur alist_Hypothesis_Normative_Theories_and_Social_Science_Evidence

Lajnah Pentashihan Mushaf Al-Quran. (2014). Tafsir AL-Quran tematik (Edisi Revi). Jakarta: Kamil Pustaka.

Mawardi, I. (2013). Pendidikan Islam transdisipliner dan sumber daya manusia Indonesia. Jurnal Pendidikan Islam, 28(2), 253-268. Retrieved from http://journal.uinsgd.ac.id/index.php/jpi /article/view/547

Meijer, R. (2010). Reform in Saudi Arabia: The gender-segregation debate. Middle East Policy, XVII(4), 80-100. Retrieved from https://www.clingendael.org/sites/default/files /pdfs/ 20100000-cdsp-artikel-rmijer.pdf

Munawwir, A. W. (1997). Al-Munawwir Kamus Arab - Indonesia terlengkap. Surabaya: Pustaka Progessif.

Nata, A. (2014). Sosiologi Pendidikan Islam. Depok: Rajawali Press.

Rahim, H. (2001). Arab baru Pendidikan Islam di Indonesia. Ciputat: Logos Wacana Ilmu.

Rami, Nasuha (2016, January 19). Personal communication.

Ridwan, Iwan (2015, October 9). Personal communication.

Suhadi, Yusuf, M., Tahun, M., Asyhari, B., \& Sudarto. (2014). Politik pendidikan agama, kurikulum 2013, dan ruang publik sekolah. Yogyakarta: Center for Religious and Cross-cultural Studies Universitas Gajah Mada.

Tiedt, P. L., \& Tiedt, I. M. (2005). Multicultural teaching a hand book of activities, information, and resources. (7, Ed.). Boston: Pearson.

Tilaar, H. A. R. (2004). Multikulturalisme tantangan-tantangan global masa depan dalam transformasi pendidikan nasional. Jakarta: Grasindo.

Tilaar, H. A. R. (2012). Perubahan sosial dan pendidikan pengantar pedagogik transformatif untuk. Indonesia. Jakarta: Rineka Cipta.

Ubaedillah, A. (2015). Pendidikan kewarganegaraan (civic education) pancasila, demokrasi, dan pencegahan korupsi. Jakarta: Prenadamedia Group. 
Irham

Wei, L. (2013). Integration of multicultural education into English teaching and learning: A case study in Liaoning police academic. Academic Publisher, 3(4), 612-619. https://doi:10.4304/tpls.3.4.612-619 